\title{
Thomas Bever o prawie W dawnej Polsce
}

\section{Wprowadzenie}

Kontakty Polski i Anglii przez stulecia były utrudnione licznymi okolicznościami - geograficznymi, językowymi, później także religijnymi. Nie oznacza to jednak, iż dwa kraje i ich mieszkańcy byli sobie zupełnie obcy. Korespondencja między królewskimi dworami wymieniana były już u początków XV w. ${ }^{1} \mathrm{~W}$ późniejszych stuleciach rozwijała się współpraca gospodarcza², zaś sami Polacy zaczęli przybywać

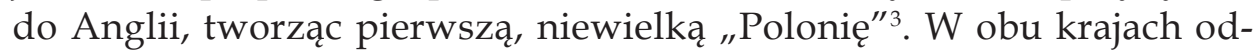
notować można także wzrastające zainteresowanie dziejami i prawem partnerów gospodarczych. Przykładowo w połowie XVII w. Arthur Duck, opisując porządki prawne różnych krajów europejskich, poświęcił obszerny rozdział Królestwu Polskiemu4. W XVIII stuleciu z kolei, kilkanaście lat po wydaniu przez Williama Blackstone'a Commentaries on the Laws of England, polski czytelnik mógł zapoznać się z rodzimym

* Dr. habil., Assistant Professor, University of Łódź; e-mail: lukasz.korporowicz@wpia. uni.lodz.pl, ORCID ID: https:/ / orcid.org/0000-0002-5725-5018.

1 O. Halecki, Anglo-Polish Relations in the Past, The Slavonic and East European Review 1934, t. 12, nr 36, s. 660.

2 E.A. Mierzwa, Anglia a Polska w okresie rewolucji purytańskiej i restauracji, Piotrków Trybunalski 2001.

3 Z. Libiszowska, Życie polskie w Londynie w XVIII wieku, Warszawa 1972.

4 Zob. Ł. Marzec, Między Rzymem, Dunajem a Murem Hadriana. Prawo rzymskie i Europa w De Usu et Authoritate Iuris Civilis Romanorum in Dominiis Principium Christianarum (1653) Arthura Ducka, Kraków 2015. 
przekładem czwartej księgi tego dzieła, przygotowanym przez Teodora Ostrowskiego ${ }^{5}$.

W latach 60. i 70. XVIII w. wykłady prawa rzymskiego prowadzone były w Oxfordzie przez dziś bliżej nieznanego prawnika Thomasa Bevera ${ }^{6}$. Ze względu na zły stan zdrowia królewskiego profesora tego przedmiotu, w $1762 \mathrm{r}$. Th. Bever podjął się prowadzenia w jego zastępstwie zajęć i kontynuował je przez kolejnych kilkanaście lat. Wykład prawnika, który zasadniczo trudnił się praktyką adwokacką w sądach kościelnych i admiralicji, odbiegał od układu wykładów prowadzonych w poprzednich dziesięcioleciach przez królewskich profesorów. Obecnie nauka dysponuje kilkoma wersjami notatek z tych zajęć ${ }^{7}$, jak również dwoma sylabusami kursu $^{8}$. Szczegółowy opis tych wykładów przedstawiony został w innym miejscu ${ }^{9}$. Istotne wydaje się natomiast, że zajęcia Th. Bevera zwieńczone były rozważaniami o charakterze prawnoporównawczym. Po zakończeniu właściwej ich części, prawnik rozpoczynał omawianie historii różnych europejskich porządków prawnych. Wydaje się, że od wspomnianego już wyżej A. Ducka zaczerpnął ich kolejność. Przedstawiane treści opracowywał jednak samodzielnie. Nieco uwagi Th. Bever poświecił również Polsce.

Poniżej przedstawiono tłumaczenie wraz z komentarzem wspomnianego wykładu dotyczącego prawa polskiego. Celem opracowania jest zaprezentowanie nowego, dotychczas niepublikowanego źródła świadczącego

5 Z. Zdrójkowski, Teodor Ostrowski (1750-1802). Pisarz dawnego polskiego prawa sądowego, Warszawa 1956, s. 175-198; W.M. Bartel, Knowledge of the English Criminal Law in Poland at the Turn of the Eighteenth and Nineteenth Century, w: The Political Context of Law, red. R. Eales, D. Sullivan, London-Ronceverte 1987, s. 106-112.

6 Więcej informacji na temat życia Th. Bevera odnaleźć można w następujących opracowaniach: Th.F. Henderson, Bever, Thomas, w: Dictionary of National Biography, t. 4, New York-London 1885, s. 446-467; J.L. Barton, Bever, Thomas, w: Oxford Dictionary of National Biography, t. 5, Oxford 2004, s. 585; Ł.J. Korporowicz, Prawo rzymskie w Anglii w XVIII wieku. Nauczanie, studia, nauka, Łódź 2019, s. 51-52.

7 All Souls College, MS 109; University of Edinburgh Archive and Manuscript Collections, Dc. 4.25; Dc. 4.26; Dc. 4.27; Dc. 4.28; Dc. 4.29.

8 The Newberry. Chicago's Independent Research Library, Case folio J 5454.822 no. 20; University of Edinburgh Archive and Manuscript Collections, Dc. 4.25.

9 Szczegółowo na temat wykładów zob. Ł.J. Korporowicz, Prawo rzymskie w Anglii..., s. 55-60. 
o znajomości historii prawa polskiego w XVIII-wiecznej Anglii. Tekst oryginalny pochodzi z notatek sporządzonych w trakcie wykładów Th. Bevera, głoszonych w roku akademickim 1772/1773. Notatki przechowywane są obecnie w archiwum Uniwersytetu w Edynburgu.

\section{Tekst angielski}

University of Edinburgh Archive and Manuscript Collections, Lectures of Thomas Bever. Part III and the Appendix (Dc. 4.29), kk. 131-135

[131] VII. We shall now bend our course to the North-eastern continent of Europe.

This vast tract of country, lying beyond the Danube, was very imperfectly known to the ancients; [132] and was distinguished, tho' without any precise limits, by the general name of Sarmatia. It was inhabited by many fierce, hardy and barbarous nations, who, tho' frequently attacked by some of the first Emperors, always presented their independency, and bid defiance to the whole power of Rome. Some of the chief of these were the Heneti, Vandals, and Burgundians, who, in the beginning of the fifth century, followed the fortunes of their other Northern neighbours into the South. Their vacancy was supplied, in the course of a few years, by another people migrating from the East, called Polaey; who occupied the deserted country, and laid the foundation of that kingdom, now so well known in modern ages, by the name of Poland. I have already, in some former discourses, made several cursory remarks upon this country, its people and government; and the more I consider it, the greater is my astonishment. It is surely much more irreconcilable to common sense, that with such infinite defects, and so few perfections, it should have already subsisted so many centuries, than that it is now making such hasty strides towards its dissolution.

Of all constitutions in Europe, none ever continued, for so long a time, in such a state of confusion and uncertainty. Tho' most of its present features are Feudal, it does not seem to have been originally of a Feudal nature; but only to have adopted some particular properties of Fiefs, as subsequent occasion required. The new inhabitants, the Polaey, obtained their settlements by the right of pre-occupancy only. Their tribes or hords were kinds of family-governments, under their respective leaders, who took possession of such particular districts; and under the names of Palatines, or Vaivodes, became, 
in time, very powerful, and grew up till they were able to impose very severe restraints, as they do at present, upon Majesty itself. From hence, you see, that they bear a much nearer resemblance to the ancient clan-ships [133] in the Highlands of Scotland, and the Septs of Ireland; which tho' not originally Feudal, were very proper stocks to ingraft Feudal seyons upon afterwards; when self-defence obliged them to form themselves after the model of their military neighbours.

They all acknowledged one Sovereign, or Generalissimo; but whether he was elective, hereditary, or testamentary, does not clearly appear; tho' generally the successors were either the sons, or some near relations of the descended Monarch; and sometimes they were appointed by will, and were usually pretty absolute. Like all the other northern Princes, they were invested both with a military and judicial authority; and determined all disputes, as they arose, either by the ancient national customs, or by the laws which they borrowed from their Saxon neighbours; and in succeeding times they supplied the defects of the foregoing by the introduction of the Civil law: for it does not appear that Poland had any written laws, or settled civil constitution of her own, till the middle of the $14^{\text {th }}$ century, when a regular body was drawn up, and published, with the consent of the Nobility, by Casimir I surnamed the Great. These were improved by several succeeding Princes, especially Sigismund II.

This last Prince dying without male issue, the Diet conferred the Crown upon Henry of Valois, brother of the French King, who soon after succeeded to the Crown of France, under the title Henry III and therefore privately withdraw from Poland; and left the Crown to the disposal of the State, who made choice of Stephen Batori, Prince of Transylvania. The new King, tho' he entirely owed his Crown to a free election, yet thought it proper to strengthen his title by an hereditary claim; he therefore married the daughter of Sigismund I and sister of Sigismund II.

This Monarch is greatly celebrated for his wisdom and policy; and particularly for having erected tribunals for the regular distribution of justice, which, before, was only occasionally administered by the King [134] and Council. From the time of Henry III i.e. from the year 1572, the Crown seems to have become entirely elective, upon which foot it has been ever since continued; the ill consequences whereof have been already fully explained in a former lecture.

The present king of Prussia, who is well acquainted with the temper of the Polish Constitution, very justly charges it with being "Tumultuous in its deliberations; uncertain in its resolutions; fickle in its engagements; eager to enter into war, without having made preparations for it, oppsessed by the rapines 
of the Great; and ill-obeyed by its troops." Mem. de Brand. Vie de Fred. Guill. In a point of the utmost consequence to their political welfare, the Poles, one would think, seem to choose a King only for the sake of shewing their contempt of Monarchy; the power however is really Aristocratical, tho' the universal passion for liberty and equality hinders the inferior gentry from owning it; and they affect to call themselves a Republic, tho' nine of ten have no liberty at all.

Learning has always been at a low ebb among people, who value themselves principally upon the exercise of arms; they seldom carry their studies further than the Latin language; tho' in this they are said to be expert enough. Their native Historians are generally very mean and contemptible. The only Polish author that I can recommend, is Goth. Lengnich, who has published two short works; one intitled Hist. Polona; wherein is a concise account of the succession of the Crown, and a few sensible conjectures concerning the origin of the nation; the other is called Jus Publicum Regni Poloni, or the public law of the State, as it prevails at this day. Both seem to have been written chiefly for the use of Count Poniatovsky, a few years since elevated to the throne; a Prince of uncommon accomplishments, and, from the accounts given of him by those who well known him, a perfect exception to the national [135] character of his rude countrymen. But such is the natural perverseness of mankind, that they seldom know how to make a proper advantage of blessings in possession. This Monarch, who does the highest honour to the Regal station, would have been intirely capable of protecting from foreign intruders, and of reforming the abuses and irregularities of that fickle and riotous Constitution. But instead of being encouraged, or even permitted to exercise those eminent talents to so laudable a purpose; his honest and patriotic efforts have been daily defeated by faction and self-interest; and his life exposed to the base attempts of every treacherous assassin. With qualities that render him worthy of the most flourishing Crown in the universe, he has now the mortification to see his dominions parcelled out, and torn off, by an insolent association of three powerful neighbours; and being neglected by his subjects, and deserted by his allies, is obliged to sit down a patient spectator of these unjust encroachments, as if he had as little interest, as he has abilities to prevent them. Such are the fatal consequences of liberty, ill understood, and worse applied. 


\section{Tekst polski}

[131] VII. Skierujmy teraz naszą uwagę ku północnowschodniej części kontynentu europejskiego.

Ten rozległy kraj leżący za Dunajem był bardzo niedokładnie poznany przez starożytnych; [132] a ogólnie określano go, choć bez wskazania dokładnych granic, jako Sarmację. Zamieszkiwało go wiele dzikich, śmiałych i barbarzyńskich narodów, które choć często atakowane przez pierwszych cesarzy, zawsze okazywały swą niezależność i stawiały opór całej potędze Rzymu. Spośród nich najważniejszymi byli Henetowie, Wandalowie i Burgundowie, którzy na początku V stulecia podążyli w ślad za innymi północnymi sąsiadami ku południu. Pustka po nich została zapełniona w ciągu kilku lat przez inny lud wędrujący ze wschodu, zwany Polanami, który zajął opuszczony kraj i położył fundamenty nowego królestwa, tak dobrze znanego w czasach współczesnych pod nazwą Polski. Już poprzednio, w trakcie niektórych wcześniejszych rozważań, poczyniłem kilka pobieżnych uwag na temat tego kraju, jego ludzi oraz rządu i im więcej myślę na jego temat, większe jest moje zadziwienie. $Z$ pewnością jest wielce nie do pogodzenia ze zdrowym rozsądkiem, że posiadając taki ogrom wad, a tak niewiele zalet, udało mu się przetrwać już tyle stuleci, a nie, jak czyni to teraz, pospiesznie kroczyć w stronę upadku.

Spośród wszystkich ustrojów Europy żaden nigdy nie trwał tak długo w stanie pomieszania i niepewności. Chociaż większość z jego obecnych cech jest feudalna, nie wydaje się, aby był on pierwotnie feudalnej natury, lecz jedynie przejął pewne szczególne cechy prawa lennego, gdy wymagała tego potrzeba. Nowi mieszkańcy, Polanie, nabyli swe osady wyłącznie w drodze zawłaszczenia. Ich plemiona czy hordy były zarządzane na sposób rodowy, [będąc] pod władzą własnych przywódców, którzy wzięli w posiadanie poszczególne dzielnice, a dzierżąc tytuły palatynów bądź wojewodów stali się z czasem bardzo potężni i wzrastali do chwili, gdy byli zdolni narzucić bardzo surowe ograniczenia Samemu [Królewskiemu] Majestatowi, jak czynią to dziś. Stąd, jak widzicie, są oni bardziej podobni do dawnych klanów [133] szkockiego Highlandu czy do irlandzkich sept, które, choć u zarania nie były feudalne, to stanowiły bardzo dobry grunt do zaszczepienia tam wraz z upływem czasu feudalnych sadzonek, gdy konieczność samoobrony zmusiła ich do przybrania formy przejętej od ich uzbrojonych sąsiadów.

Wszyscy oni uznawali jednego Władcę, Generalissimo, jednak nie jest jasne czy był on wybierany, dziedziczny czy wskazywany w testamencie. Niemniej, co do zasady następcami byli bądź synowie, bądź inni blisko spokrewnieni 
ze zmarłym Monarchą. Czasami byli oni ustanawiani z woli i zwykle byli raczej autorytarni [w swych rządach]. Podobnie jak wszystkim innym książętom północy, powierzano im władzę zarówno wojskową jak i sądową i rozstrzygali wszelkie spory, które powstawały, czy to na podstawie dawnych krajowych zwyczajów, czy na podstawie praw, które zapożyczyli od swych saksońskich sąsiadów, a w późniejszych czasach naprawili błędy przeszłości poprzez wprowadzenie prawa rzymskiego. Wydaje się bowiem, że Polska nie miała żadnych spisanych praw bądź ustanowionego własnego ustroju państwowego aż do połowy XIV stulecia, gdy Kazimierz I, zwany Wielkim, za zgodą szlachty sporządził i wydał zbiór praw podstawowych. Były one udoskonalane przez kilku kolejnych władców, zwłaszcza przez Zygmunta II.

[Gdy] ten ostatni monarcha umarł bez męskiego potomka, Sejm powierzył koronę Henrykowi Walezemu, bratu króla Francji, który wkrótce odziedziczył koronę Francji, przyjmując tytuł Henryka III, i z tego względu potajemnie opuścił Polskę. Pozostawił koronę do dyspozycji państwa, które wybrało Stefana Batorego, księcia Transylwanii. Nowy król, choć w całości zawdzięczał koronę wolnej elekcji, jednak zamyślał wzmocnić swój tytuł przez nabycie roszczenia opartego na dziedziczeniu. Z tego względu poślubił córkę Zygmunta I, a siostrę Zygmunta II.

Władca ten zdobył wyjątkowe poważanie ze względu na swoją mądrość i politykę; w szczególności ze względu na stworzenie trybunałów mających stale zarządzać wymiarem sprawiedliwości ${ }^{10}$, wcześniej jedynie sporadycznie sprawowanym przez Króla [134] i przez Radę. Wydaje się, że od czasów Henryka III, t.j. od roku $1572^{11}$, Korona stała się zupełnie elekcyjna, w następstwie czego zawsze już tak jest (złe następstwa tego stanu rzeczy zostały w całości wyjaśnione w poprzednim wykładzie).

Obecny król Prus, który jest dobrze zaznajomiony ze strukturą polskiego ustroju, bardzo słusznie zarzuca mu bycie „burzliwym w dyskusjach, niepewnym w postanowieniach, zmiennym w przedsięwzięciach, chętnym do rozpoczęcia wojny bez poczynienia przygotowań do niej, obezwładnionym żądzą wielkości; i nie słuchanym przez swych żołnierzy". Mem de Brand. Vie. De Fred. Guill. Biorąc pod uwagę najpoważniejszą przesłankę ich politycznego powodzenia, ktoś mógłby pomyśleć, że Polacy zdają się wybierać króla jedynie po to, by okazać swe lekceważenie wobec monarchii. Władza jednak jest tak naprawdę arystokratyczna ${ }^{12}$, jako że powszechna zaciekłość na

10 Dosłownie „zarządzać sprawiedliwością".

11 Informacja nie jest precyzyjna. W 1572 r. zmarł Zygmunt II August. Henryk Walezy został wybrany dopiero na sejmie elekcyjnym w maju $1573 \mathrm{r}$.

12 W znaczeniu „władza jest w rękach arystokracji”. 
tle wolności i równości przeszkadza niższej szlachcie w jej posiadaniu. Choć dążą do tego, by nazywać siebie Republiką, dziewięciu z dziesięciu nie ma żadnej wolności.

Wiedza zawsze była bardzo nisko postrzegana przez ludzi, którzy cenią siebie przede wszystkim ze względu na biegłość w fechtunku. Rzadko oddają się pogłębianiu wiedzy dalej, niż nauce łaciny, a jednak i tak uważa się ich za dość wykształconych. Ich rodzimi historycy są ogólnie bardzo złośliwi i podli. Jedynym polskim autorem, którego mogę polecić jest Goth. Lengnich, który wydał dwie krótkie prace; jedna zatytułowana Hist. Polona., w której znajduje się zwięzły opis dziedziczenia korony oraz trochę rozsądnych domysłów dotyczących pochodzenia narodu; nazwa drugiej to Jus Publicum Regni Poloni bądź prawo publiczne państwowe, jak dziś się zwykło [mówić]. Obie [prace] wydają się być napisane przede wszystkim na użytek Księcia Poniatowskiego, kilka lat po wyniesieniu go na tron. Jest to książę nadzwyczajnych zdolności oraz, sądząc na podstawie opisów przedstawionych przez tych, którzy go dobrze znają, doskonały przykład sprzeniewierzenia się narodowemu charakterowi jego niewychowanych rodaków. Lecz taka jest naturalna przewrotność ludzi, że rzadko wiedzą, jak właściwie odnieść korzyść z posiadanych darów ${ }^{13}$. Monarcha ten, który czyni najwyższy zaszczyt królewskiemu urzędowi, byłby w pełni zdolny do ochrony [państwa] przed obcymi natrętami, a także do zreformowania nadużyć oraz nieprawidłowości tego kapryśnego i buntowniczego ustroju. Lecz zamiast być zachęcanym, bądź chociaż mieć pozwolenie na wykorzystywanie znakomitych talentów dla tak chwalebnego celu, jego szczere i patriotyczne starania są stale udaremniane przez stronnictwa i prywatne interesy, jego życie zaś jest narażone na nikczemne próby zamachu ze strony pierwszego lepszego zdradzieckiego łotra. Mając cechy, które czynią go godnym [posiadania] najbardziej wyjątkowej korony we wszechświecie, musi teraz upokorzony patrzeć jak jego dominia są dzielone i rozdzierane przez pyszne sprzysiężenie trzech potężnych sąsiadów, a będąc lekceważony przez poddanych i opuszczony przez sprzymierzeńców, zmuszony jest siedzieć niczym cierpliwy obserwator tych niesłusznych naruszeń, jak gdyby niewiele się nimi interesował, podczas gdy w istocie miał możliwości im zapobiec. ------- Oto są makabryczne skutki wolności źle rozumianej i źle stosowanej.

13 Dosłownie „błogosławieństw”. 


\section{Komentarz}

Pojęcie Sarmacji na określenie obszaru Europy Wschodniej znane było już autorom starożytnym (Tacyt, Ptolemeusz) ${ }^{14}$. Zabieg ten powtarzany był także przez autorów późniejszych i nie dziwi jego pojawienie się $\mathrm{u}$ Th. Bevera. Nie powinien zresztą dziwić także u angielskiego prawnika brak wzmianki dotyczącej Celtów. Początków celtologii, jako samodzielnej dyscypliny naukowej należy poszukiwać dopiero w XIX stuleciu ${ }^{15}$, choć już w XVII i XVIII w. można upatrywać korzeni studiów nad językami celtyckim ${ }^{16}$.

Ze względu na słabą znajomość dziejów dawnej „barbarzyńskiej” Europy, Th. Bever uznał za najważniejsze pośród sarmackich plemion: Henetów, Wandalów oraz Burgundów. Oczywiście dwa ostatnie plemiona są dobrze znane z pism autorów starożytnych. Wbrew poglądowi Th. Bevera były to plemiona należące do grupy wschodniogermańskiej. Odmiennie prezentuje się jednak kwestia Henetów. Lud ten po raz pierwszy pojawia się na kartach Iliady Homera ${ }^{17}$. W polskiej tradycji literackiej i historiograficznej epoki późnego średniowiecza i nowożytnej Henetowie wymieniani byli jako przodkowie Polaków ${ }^{18}$. Thomas Bever nie utożsamia jednak starożytnego ludu z Polakami. Wspomina zaś, iż wymienione przez niego plemiona opuściły w V w. dotychczasowe terytoria i ustąpiły przybyłym ze wschodu Polanom. Prawnik milczy na temat innych Słowian.

Stosunkowo sporo miejsca Th. Bever poświęcił organizacji rodowej Piastów. Co ciekawe, uznał plemienny ustrój Piastów za wzorzec dla późniejszych struktur administracyjnych państwa polskiego. Jego zdaniem różne rody osiedliły się na kilku sąsiadujących terytoriach. Ich naczelnicy rodowi, mający przybrać nazwę palatynów bądź wojewodów, zaczęli

14 Zob. Greckie i łacińskie źródła do najstarszych dziejów Słowian, cz. 1. Do VIII wieku, tłum. i oprac. M. Plezia, Poznań-Kraków 1952, s. 34-46.

15 Na temat początków badań celtologicznych zob. D. Wiley, Celtic Studies, Early History of the Field, w: Celtic Culture. A Historical Encyclopedia, t. 1. A-Celti, red. J.C. Koch, Santa Barbara-Denver-Oxford 2006, s. 385-387.

16 Jednym z pierwszych badaczy języków celtyckich był inny XVIII-wieczny oksfordczyk, prawnik i filolog, Sir William Jones. Na jego temat zob. przykładowo M.J. Franklin, Orientalist Jones. Sir William Jones, Poet, Lawyer, and Linguist. 1764-1794, Oxford 2011.

17 Homer, Illiada II, 851-855.

18 Zob. Z. Nowak, Jan Rybiński. Zapomniany poeta pomorski doby Odrodzenia, Pamiętnik Literacki 1961, t. 52, nr 4, s. 339. 
rosnąć w siłę, tak iż ostatecznie zdolni byli ograniczyć w prawach monarchów. To ostatnie twierdzenie stanowi dobrą ilustrację metody przyjętej przez Th. Bevera. Polanie i Polacy okresu piastowskiego stają się w jego wywodzie jednym i tym samym organizmem państwowym. Nadużycia nowożytnych magnatów i - jak można przypuszczać - obstrukcja sejmowa zostają przez prawnika uznane za obecne w Polsce średniowiecznej. Interesująca jest natomiast analogia, którą wykładowca wieńczy swoje dotychczasowe rozważania. W jego przekonaniu Polanie podobni byli pod względem organizacji rodowej do szkockich klanów czy irlandzkich sept ${ }^{19}$.

Kolejny akapit rozważań Th. Bevera dotyczy ustroju Polski. Nad wszystkimi wspomnianymi uprzednio plemionami miał panować jeden władca. W trakcie wywodu prawnika staje się on nagle władcą Polski - raz nazywany królem, raz księciem, kiedy indziej monarchą. Prawnik wskazuje, że zasady jego wyboru nie były jednoznacznie ustalone, jednak z pewnością dysponował on władzą absolutną w sprawach wojskowych i sądowych. Z punktu widzenia historii prawa intersujące jest jednak, że monarcha miał zaprowadzać sprawiedliwość, opierając się wpierw na lokalnych zwyczajach, z czasem zaś również na prawach zapożyczonych „od saksońskich sąsiadów" (ostatecznie zaczęto odwoływać się także do prawa rzymskiego). Wprawdzie wypowiedź Th. Bevera należy ocenić jako dość ogólną, jednak warto zwrócić uwagę na kilka szczegółów, które być może błędnie zinterpretowane przez prawnika, w rzeczywistości nawiązują do dziejów prawa polskiego. Nie ulega wątpliwości, że początkowo podstawowym źródłem prawa był w dawnej Polsce zwyczaj, następnie spisany w postaci Statutów Kazimierza Wielkiego (o których zresztą Th. Bever wspomina, jako o pierwszym pomniku dawnego prawa polskiego). Zapożyczenia wzięte "od swych saksońskich sąsiadów" wydają się korespondować nie tyle z prawami germańskiego ludu Sasów, co z niemieckim prawem miejskim (prawem saskim, prawem magdeburskim), które w okresie jagiellońskim faktycznie coraz szerzej zaczęło być wykorzystywane w polskich miastach, a w kolejnych stuleciach bywało także źródłem porównań stosowanych w pismach polskich prawników ${ }^{20}$. Tego rodzaju przejście, jak to zostało już

19 Użyte porównanie nie wydaje się jednak w pełni właściwe. Tak klany, jak i septy pozostawały zawsze strukturami rodzinnymi, nie zaś, jak tego chce Th. Bever półpaństwowymi. W odniesieniu do dawnej Irlandii właściwsza byłaby raczej analogia do túath, zob. F. Kelly, A Guide to Early Irish Law, Dublin 1988, s. 3-4.

20 W. Uruszczak, Historia państwa i prawa polskiego, t. 1, Warszawa 2015, s. 179-181. 
uprzednio wskazane, nie było czymś niezwykłym w wywodzie Th. Bevera, który okres średniowieczny traktuje jako „monolit”, w ramach którego nie dochodziło do poważniejszych zmian. Wreszcie odwołanie do prawa rzymskiego, stanowić może bezpośrednie nawiązanie do poprzedniego wątku. W polskiej literaturze prawniczej już od XVI w. dyskutowano bowiem o zakresie wykorzystywania prawa rzymskiego jako porządku subsydiarnego w stosunku do prawa miejskiego. Zdaniem historyków prawa nie był to problem teoretyczny, lecz jak najbardziej praktyczny, a badania K. Bukowskiej wykazały skalę rzymskich zapożyczeń w orzecznictwie np. sądów krakowskich epoki nowożytnej ${ }^{21}$. Można jedynie wyrazić ubolewanie, że mimo upływu wielu lat od opublikowania wyników badań przez wspomnianą badaczkę, wątek ten nie znalazł się w orbicie zainteresowań szerszego grona polskich romanistów i historyków prawa. Prawnik zamyka swoje dotychczasowe rozważania wskazując na znaczenie Statutów Kazimierza Wielkiego.

Okres jagielloński ograniczył Th. Bever do ogólnego stwierdzenia, że kolejni władcy Polski podejmowali działania reformatorskie, lecz najpoważniejsze kroki w tym zakresie podjął dopiero Zygmunt II August. Wykładowca nie opisuje wspomnianych reform. Zresztą odwołanie do ostatniego władcy dynastii Jagiellonów pozostaje nieco zagadkowe. Przepuszczać można raczej, że Anglik miał na myśli program reform przedkładanych za rządów kilku ostatnich Jagiellonów, nie zawsze jednak inicjowanych czy aprobowanych przez władców. Mowa tu o Statucie Jana Łaskiego, Formula processus, zbiorze Macieja Śliwnickiego czy Korekturze Mikołaja Taszyczkicego ${ }^{22}$.

Po krótkim lecz szczegółowym passusie poświęconym pierwszym królom elekcyjnym, Th. Bever skupił się na czasach sobie współczesnych. Jedynym wartym, jego zdaniem, wydarzeniem z zakresu dziejów prawa, które wiązało się z panowaniem władców elekcyjnych było utworzenie Trybunału Koronnego za rządów Stefana Batorego ${ }^{23}$. Wątpliwość budzić może użyta przez Th. Bevera wzmianka na temat wcześniejszego sprawowania wymiaru sprawiedliwości „przez Króla i przez Radę”. Być

${ }^{21}$ K. Bukowska, Orzecznictwo krakowskich sądów wyższych w sporach o nieruchomości miejskie (XVI-XVIII w.). Studium z historii prawa rzymskiego w Polsce, Warszawa 1967.

${ }^{22}$ Zob. Z. Kaczmarek, B. Leśnodorski, Historia państwa i prawa Polski, t. 2. Od połowy XV wieku do r. 1795, Warszawa 1966, s. 21-22.

23 O genezie Trybunału i jego powołaniu zob. ibidem, s. 153-154. 
może prawnik nawiązał tutaj do Rady Królewskiej (Curia Regis), z której wykształcił się późniejszy senat. Wydaje się, że wzmianka na temat sprawowania wymiaru sprawiedliwości dotyczyć mogła orzekania przez króla in curia, tj. w sądzie nadwornym - o czym wspominał swego czasu Z. Kaczmarek ${ }^{24}$. Nie wykluczone również, że Th. Bever dopuścił się w tym miejscu uproszczenia i przełożył doświadczenia angielskie na grunt polski. Wówczas orzekanie przez króla i Radę mogłoby być nawiązaniem do genezy angielskiego sądownictwa królewskiego, czy sprawowania wymiaru sprawiedliwości przez tzw. Tajną Radę (Privy Council) ${ }^{25}$.

Prawnik wskazał na dysproporcje i ograniczenia związane z dostępem do rządów w Polsce przez niższą szlachtę. Podkreślił, że władzę sprawuje arystokracja, zaś większość mieszkańców kraju nie cieszy się żadnymi wolnościami obywatelskimi, choć sam kraj nazywany jest republiką ${ }^{26}$.

Thomas Bever podał także kilka zaskakujących informacji na temat stanu nauki w Polsce. Stwierdził, że nie stała ona nigdy na wysokim poziomie, poza znajomością łaciny, która pozwalała sądzić Polakom, iż posiadają wszechstronną wiedzę. Wyraził także pogląd, iż poza Gotfrydem Bogumilem Lengnichem, trudno odnaleźć w Polsce dobre opracowania poświęcone historii. W swoim wykładzie wskazał na dwa traktaty gdańszczanina: Historia Polona a Lecho ad Augusti II mortem, wydana w $1741 \mathrm{r}$. oraz Ius Publicum Regni Poloni, opracowanie pochodzące z lat 1742-1746. Można mieć jednak wątpliwość, czy Th. Bever czytał wspomniane prace. Stwierdził bowiem, iż zostały one napisane „na użytek Księcia Poniatowskiego, kilka lat po wyniesieniu go na tron". Twierdzenie takie jest oczywiście niesłuszne, bowiem Stanisław August Poniatowski wybrany został królem dopiero w 1764 r. Tłumaczyć może Anglika natomiast

24 Ibidem, s. 152.

25 Ł.J. Korporowicz, Komitet Sadowy Tajnej Rady (Judicial Committee of the Privy Council) - sadowy relikt Imperium Brytyjskiego, w: Imperium Brytyjskie. Rozważania interdyscyplinarne, red. K. Kujawińska-Courtney, Z. Bednarek, Łódź 2019, s. 66-68.

${ }^{26}$ Warto nadmienić, iż polski ustrój był przedmiotem analiz oświeceniowych autorów francuskich - Woltera (Essai historique et critique sur les dissensions des eglises de Pologne, Basle 1767) i Jean-Jacques'a Rousseau (Considérations sur le gouvernement de Pologne, et sur sa réformation projettée, Londres 1782; pol. wyd.: Uwagi o rzadzie polskim, tłum. i oprac. M. Starzewski, Kraków 1924). Trzeba jednak wyjaśnić, iż zainteresowanie tych autorów sprawą polską brało się z poduszczenia innych - Wolter pisał na zlecenie Katarzyny Wielkiej, zaś J.J. Rousseau z inspiracji konfederaty barskiego Michała Wielhorskiego. 
fakt, iż drugie, poprawione wydanie Ius Publicum, ukazało się w latach 1765-1766, a więc wkrótce po objęciu rządów przez króla.

Finalną część wykładu Th. Bever poświęcił postaci ostatniego króla Polski. Na uwagę zasługuje fakt, że dał on pośrednio do zrozumienia, iż informacje dotyczące monarchy czerpał od osób z nim związanych (,sądząc na podstawie opisów przedstawionych przez tych, którzy go dobrze znają"). Wydaje się, że wykładowca mógł mieć na myśli ambasadora polskiego przy Dworze Św. Jakuba, Tadeusza Burzyńskiego ${ }^{27}$. W lipcu 1771 r., niecałe dwa lata przed wygłoszeniem komentowanego wykładu, polski dyplomata otrzymał w Oxfordzie honorowy doktorat prawa rzymskiego ${ }^{28}$. Była to powszechnie stosowana praktyka $\mathrm{w}$ odniesieniu do zagranicznych posłów przybywających do Londynu, poświadczona w XVIII stuleciu licznymi przykładami ${ }^{29}$. Istotny pozostaje jednak fakt, że osobą przedstawiającą $\mathrm{w}$ tym czasie kandydatów do stopnia doktora prawa rzymskiego władzom uczelni był zwyczajowo Th. Bever. Mógł on w związku z tym wydarzeniem rozmawiać z T. Burzyńskim. Niewykluczone, że mężczyźni znali się także z Londynu, gdzie Th. Bever spędzał większość zawodowego czasu.

Niewykluczone, że prawnik mógł opierać się także na relacjach otrzymanych od osób, które poznały Stanisława Augusta w trakcie jego pobytu w Anglii. W 1754 r. przyszły polski monarcha przebywał w Anglii za sprawą swojego przyjaciela Charlesa Hanbury'ego Williamsa (1708-1759). Mężczyźni poznali się kilka lat wcześniej, a rodzaj łączącej ich znajomości rodził plotki ${ }^{30}$. Niemniej, Poniatowski zafascynował się kulturą angielską i pozostawał pod jej dużym wpływem. Wymiernym skutkiem jego podróży po Anglii było nawiązanie kontaktów z przedstawicielami angielskich elit (politykami i dyplomatami), w tym z Charles'em Yorkiem, synem premiera, prawnikiem i członkiem Parlamentu ${ }^{31}$.

Fragment poświęcony Stanisławowi Augustowi Poniatowskiemu uznać można za prawdziwy panegiryk. Jest to postawa zupełnie

27 Zob. Z. Libiszowska, Misja polska w Londynie w latach 1769-1795, Łódź 1966, passim.

28 Alumni Oxonienses. The Members of the University of Oxford, 1715-1886. Later Series. $A-D$, red. J. Foster, Oxford 1882, s. 105.

29 Ł.J. Korporowicz, Prawo rzymskie w Anglii..., s. 114-117.

30 R.J. Butterwick, Wkład Sir Charlesa H. Williamsa w ksztattowanie osobowości i pogląów Stanisława A. Poniatowskiego, Acta Universitatis Lodziensis. Folia Historica 1996, t. 57, s. 61.

31 R. Butterwick, Poland's Last King and English Culture. Stanistaw August Poniatowski. 1732-1798, Oxford 1998, s. 124-145. 
wyjątkowa, gdyż zasadniczo elity intelektualne zachodniej Europy były $\mathrm{w}$ tym czasie zalewane i $\mathrm{w}$ znacznym stopniu ulegały prorozbiorowej propagandzie prowadzonej przez władze pruskie i rosyjskie. Anglik uznał tymczasem polskiego króla za przeciwieństwo wszystkich cech narodowych, które przypisał wcześniej Polakom. Warto w tym miejscu zaznaczyć, że Th. Bever pozostawał zasadniczo krytyczny wobec Polaków. Dał temu wyraz kilkukrotnie. Niektóre jego wypowiedzi uznać można wręcz za obelżywe. Zdumiewał się na przykład, jak Polacy mogli przetrwać tak wiele stuleci „posiadając taki ogrom wad, a tak niewiele zalet”. Najszersze wyliczenie wad polskiego ustroju, które jednocześnie było wyliczeniem przywar polskiego charakteru narodowego, dał jednak w ślad za Fryderykiem II, królem pruskim i elektorem brandenburskim, wrogo nastawionym względem Polaków. Prawnik wykorzystał fragment angielskiego tłumaczenia pracy pruskiego monarchy zatytułowanej Mémoires pour servir a l'histoire de la Maison de Brandebourg32.

Z pewnością Th. Bever nie znał późniejszych wypowiedzi króla pruskiego, które były krytyczne również wobec ostatniego króla Polski. Prawnik był w jakiś sposób zauroczony postacią polskiego monarchy, tak dalece, iż stwierdził, że król nabył cechy, „które czynią go godnym [posiadania] najbardziej wyjątkowej korony we wszechświecie". Wspomniał także o próbach zabicia władcy, co zdaje się być nawiązaniem do nieudanej ostatecznie próby porwania Stanisława Augusta przez konfederatów barskich w 1771 r. ${ }^{33}$ Za winnych niepowodzeń Polski uznał przeciwników króla, którzy mieli utrudniać jego reformatorskie plany.

Choć ogólny ton wypowiedzi Th. Bevera pozostaje niekorzystny dla Polski, jednak podsumowanie wykładu pozwala uznać Anglika za silącego się na choć odrobinę obiektywności. Opisując pierwszy rozbiór Polski, oksfordczyk stwierdził, że został on dokonany "przez pyszne sprzysiężenie trzech potężnych sąsiadów”, zaś sam rozbiór uznał za „niesłuszne naruszenie" 34 .

32 [Fryderyk II Wielki], CEuvers de Frédéric le Grand, t. 1. Mémoires pour servir a l'histoire de la Maison de Brandebourg, Berlin 1846, s. 56; [Fryderyk II Wielki], Memoirs of the House of Brandenburg, London 1751, s. 82.

33 Więcej zob. J. Sondel, Prawo rzymskie w procesie sprawców porwania Stanisława Augusta, w: Crimina et mores. Prawo karne i obyczaje w starożytnym Rzymie, red. M. Kuryłowicz, Lublin 2001, s. 191-200.

34 Po drugim rozbiorze Polski znacznie mocniej w sprawie rozbiorów wypowiadał się Edmund Burke: „no wise or honest man can approve of that partition, or can contemplate 


\section{Bibliografia}

Bartel W.M., Knowledge of the English Criminal Law in Poland at the Turn of the Eighteenth and Nineteenth Centuries, w: The Political Context of Law, red. R. Eales, D. Sullivan, London-Ronceverte 1987.

Barton J.L., Bever, Thomas, w: Oxford Dictionary of National Biography, vol. 5, Oxford 2004.

Bukowska K., Orzecznictwo krakowskich sądów wyższych w sporach o nieruchomości miejskie (XVI-XVIII w.). Studium z historii prawa rzymskiego w Polsce, Warszawa 1967.

Butterwick R.J., Wkład Sir Charlesa H. Williamsa w ksztattowanie osobowości i pogladów Stanistawa A. Poniatowskiego, Acta Universitatis Lodziensis. Folia Historica 1996, t. 57.

Butterwick R., Poland's Last King and English Culture. Stanistaw August Poniatowski. 1732-1798, Oxford 1998.

Burke E., Observations on the Conduct of the Minority, Particularly in the Last Session of Parliament, w: The Works of the Right Honorable Edmund Burke, t. 5, Boston 1866.

Franklin M.J., Orientalist Jones. Sir William Jones, Poet, Lawyer, and Linguist. 1746-1794, Oxford 2011.

[Fryderyk II Wielki], CEuvers de Frédéric II roi de Prusse, t. 1. Mémoires pour servir a l'histoire de la Maison de Brandebourg, Berlin 1846.

[Fryderyk II Wielki], Memoirs of the House of Brandenburg, London 1751.

Greckie i łacińskie źródła do najstarszych dziejów Słowian, cz. 1. Do VIII wieku, tłum. i oprac. M. Plezia, Poznań-Kraków 1952.

Halecki O., Anglo-Polish Relations in the Past, The Slavonic and East European Review 1934, t. 12, nr 36.

Henderson Th.F., Bever, Thomas, w: Dictionary of National Biography, t. 4, New York-London 1885.

Kelly F., A Guide to Early Irish Law, Dublin 1988.

Kaczmarek Z., B. Leśnodorski, Historia państwa i prawa Polski, t. 2. Od połowy XV wieku do r. 1795, Warszawa 1966.

Korporowicz Ł.J., Prawo rzymskie w Anglii w XVIII wieku. Nauczanie, studia, nauka, Łódź 2019.

Korporowicz Ł.J., Komitet Sadowy Tajnej Rady (Judicial Committee of the Privy Council) - sadowy relikt Imperium Brytyjskiego?, w: Imperium Brytyjskie. Rozważania interdyscyplinarne, red. K. Kujawińska-Courtney, Z. Bednarek, Łódź 2019.

Libiszowska Z., Misja polska w Londynie w latach 1769-1795, Łódź 1966.

Libiszowska Z., Życie polskie w Londynie w XVIII wieku, Warszawa 1972.

it without prognosticating great mischief from it to all countries at some future time", E. Burke, Observations on the Conduct of the Minority, Particularly in the Last Session of Parliament, w: The Works of the Right Honorable Edmund Burke, t. 5, Boston 1866, s. 25. 
Marzec Ł., Między Rzymem, Dunajem a Murem Hadriana. Prawo rzymskie i Europa $w$ De Usu et Authoritate Iuris Civilis Romanorum in Dominiis Principium Christianarum (1653) Arthura Ducka, Kraków 2015.

Mierzwa E.A., Anglia a Polska w okresie rewolucji purytańskiej i restauracji, Piotrków Trybunalski 2001.

Nowak Z., Jan Rybiński. Zapomniany poeta pomorski doby Odrodzenia, Pamiętnik Literacki 1961, t. 52, nr 4.

Rousseau J.J., Considérations sur le gouvernement de Pologne, et sur sa réformation projettée, Londres 1782.

Rousseau J.J., Uwagi o rządzie polskim, tłum. i oprac. M. Starzewski, Kraków 1924.

Sondel J., Prawo rzymskie w procesie sprawców porwania Stanistawa Augusta, w: Crimina et mores. Prawo karne i obyczaje w starożytnym Rzymie, red. M. Kuryłowicz, Lublin 2001.

Uruszczak W., Historia państwa i prawa polskiego, t. 1, Warszawa 2015.

Voltaire, Essai historique et critique sur les dissensions des eglises de Pologne, Basle 1767.

Wiley D., Celtic Studies, Early History of the Field, w: Celtic Culture. A Historical Encylopedia, t. 1. A-Celti, red. J.C. Koch, Santa Barbara-Denver-Oxford 2006.

Zdrójkowski Z., Teodor Ostrowski (1750-1802). Pisarz dawnego polskiego prawa sadowego, Warszawa 1956.

\section{Streszczenie}

Thomas Bever był angielskim prawnikiem-cywilistą, który nauczał prawa rzymskiego w osiemnastowiecznym Oxfordzie. Końcowa część jego wykładów stanowiła rodzaj porównawczego opisu różnych europejskich porządków prawnych. Wśród nich, Th. Bever przedstawił również historię dawnego prawa polskiego. Był to rodzaj krótkiego opisu najważniejszych wydarzeń w dziejach historii prawa w Polsce, począwszy od czasów legendarnej Sarmacji, aż po współczesne wydarzenia związane z rządami Stanisława Augusta Poniatowskiego oraz rozbiorami Polski.

Powyższa praca zawiera oryginalny tekst wykładu Th. Bevera (który stanowi fragment jego notatek wykładowych znajdujących się obecnie w archiwum Uniwersytetu w Edynburgu), polskojęzyczne tłumaczenie wykładu oraz komentarz.

Słowa kluczowe: Oxford, wykłady, prawo porównawcze, historia prawa, Polska 


\section{THOMAS BEVER ON THE OLD POLISH LAW}

\section{Sum mary}

Thomas Bever was an English civil lawyer who taught Roman law in the $18^{\text {th }}$ century Oxford. The final part of his lectures was kind of a comparative approach to the different European legal systems. Among them, Th. Bever presented the history of an old Polish law. His lecture was a type of a short description of the most important facts of Polish legal history, since the legendary times of Sarmatia until the modern events of the reign of Stanisław August Poniatowski and the first partition of Poland.

The foregoing work presents the original text of Th. Bever's lecture (which is part of his lecture notes currently stored by the archives of the University of Edinburgh), the Polish translation of the lecture and its commentary.

Key words: Oxford, lectures, comparative law, legal history, Poland

\section{ТОМАС БЕВЕР О ЗАКОНЕ В ДАВНЕЙ ПОЛЬШЕ \\ Резиме}

Томас Бевер был английским юристом, который специализировался в области гражданского права. Преподавал римское право в Оксфорде восемнадцатого века. Заключительная часть его лекций представляла собой своего рода сравнительное описание различных европейских правовых порядков. Среди них Т. Бевер также представил историю права давней Польши (Речи Посполитой). Это было своего рода краткое описание важнейших событий в истории права в Польше, начиная с времен легендарной Сарматии - по современные события, связанные с правлением Станислава Августа Понятовского и разделами Польши.

Настоящая работа содержит оригинальный текст лекции Т. Бевера (лекция является частью его конспектов лекций, которые в настоящее время хранятся в архивах Эдинбургского университета), польский перевод лекции, а также комментарий.

Ключевые слова: Оксфорд, лекции, сравнительное правоведение, история права, Польша 
